US Army Corps

of Engineers

Engineer Research and

Development Center

Aquatic Plant Control Research Program

\title{
Status of Hydrellia spp. (Diptera: Ephydridae) Release Sites in Texas as of December 1998
}

by Michael J. Grodowitz, Jan E. Freedman, Alfred F. Cofrancesco, ERDC Ted D. Center, Aquatic Plant Research Facility

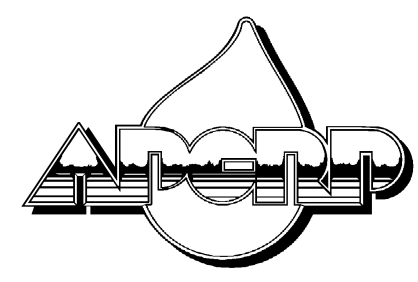


The contents of this report are not to be used for advertising, publication, or promotional purposes. Citation of trade names does not constitute an of ficial endorsement or approval of the use of such commercial products.

The findings of this report are not to be construed as an official Department of the Army position, unless so designated by other authorized documents. 


\section{Status of Hydrellia spp. (Diptera: Ephydridae) Release Sites in Texas as of December 1998}

by Michael J. Grodowitz, Jan E. Freedman, Alfred F. Cofrancesco

Environmental Laboratory

U.S. Army Engineer Research and Development Center

3909 Halls Ferry Road

Vicksburg, MS 39180-6199

Ted D. Center

Aquatic Plant Research Facility

3205 College Avenue

Fort Lauderdale, FL 33314

Final report

Approved for public release; distribution is unlimited 


\section{Waterways Experiment Station Cataloging-in-Publication Data}

Status of Hydrellia spp. (Diptera: Ephydridae) release sites in Texas as of December 1998 / by Michael J. Grodowitz ... [et al.] ; prepared for U.S. Army Corps of

Engineers.

31 p. : ill. ; $28 \mathrm{~cm}$. - (Miscellaneous paper ; A-99-1)

Includes bibliographic references.

1. Hydrilla -Biological control. 2. Hydrilla - Management - Texas. 3. Aquatic plants - Management - Texas. I. Grodowitz, Michael Jay. II. United States. Army. Corps of Engineers. III. U.S. Army Engineer Research and Development Center. IV. Aquatic Plant Control Research Program (U.S. Army Engineer Research and Development Center) V. Series: Miscellaneous paper (U.S. Army Engineer Research and Development Center) ; A-99-1.

TA7 W34m no.A-99-1 


\section{Contents}

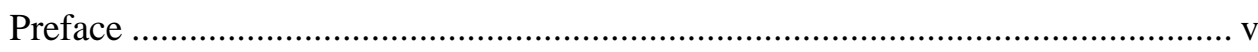

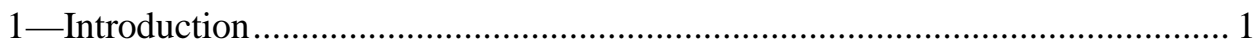

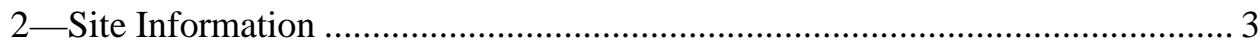

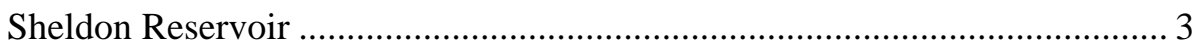

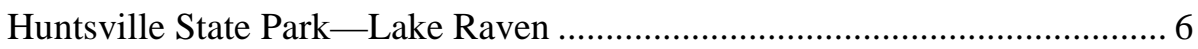

Coleto Creek Reservoir.......................................................................... 11

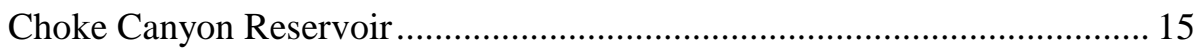

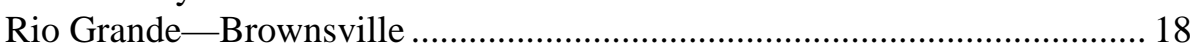

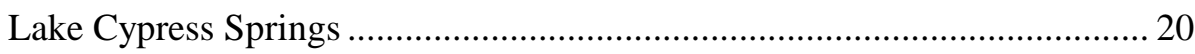

Lewisville Aquatic Plant Facility............................................................ 21

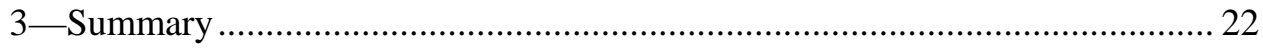

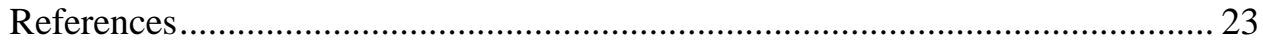

SF 298

\section{List of Figures}

Figure 1. Map of Texas showing location of Hydrellia spp. release sites and additional sites where populations of Hydrellia spp. have been identified but no known releases occurred............................... 2

Figure 2. Sheldon Reservoir pond during October 1992 .............................. 4

Figure 3. Sheldon Reservoir pond in September 1994 _................................... 5

Figure 4. Close-up of hydrilla infestation on Sheldon Reservoir pond in

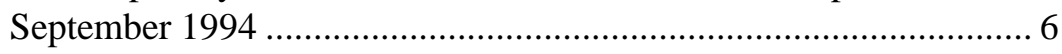

Figure 5. Sheldon Reservoir pond taken during September 1998 ................... 7 
Figure 6. Close-up of submersed vegetation in Sheldon Reservoir pond ......... 8

Figure 7. Close-up of submersed vegetation in Sheldon Reservoir pond (Hydrilla was much reduced in this area with other species of vegetation, especially coontail and Eurasian watermilfoil, present in high quantities 9

Figure 8. Close-up of submersed vegetation at Lake Raven release site during August 1994 10

Figure 9. Lake Raven Hydrellia balciunasi release site during September 1998

Figure 10. Close-up of submersed vegetation in Lake Raven

Hydrellia balciunasi release site during September 1998

(Note holes in hydrilla canopy and less dense nature of infestation)

Figure 11. Close-up of submersed vegetation in Lake Raven Hydrellia

balciunasi release site during September 1998 (Note how hydrilla, while present, has not reached surface in many areas and presence of broken stems floating on water surface)

Figure 12. Coleto Creek Reservoir original cove release site during August 1994. 14

Figure 13. Close-up of original Coleto Creek Reservoir cove release site during September 1994 15

Figure 14. Close-up of original Coleto Creek Reservoir cove release site during September 1998 (There is little hydrilla remaining at this area with only a few scattered stems reaching water surface)

Figure 15. Close-up of original Coleto Creek Reservoir cove release site during September 1998 (Note how there are only a few scattered stems reaching water surface. Of remaining stems, over 80 percent had at least some immature Hydrellia leaf damage) 17

Figure 16. Coleto Creek release site adjacent to dam; August 1998 18

Figure 17. Close-up of hydrilla at "dam" Coleto Creek release site during August 1998 19

Figure 18. Close-up of hydrilla approximately $1 \mathrm{~km}$ upstream of original cove release site on Coleto Creek Reservoir during August 1998 


\section{Preface}

The work reported herein was conducted as part of the Aquatic Plant Control Research Program (APCRP), Work Unit 33028. The APCRP is sponsored by the Headquarters, U.S. Army Corps of Engineers (HQUSACE), and is assigned to the U.S. Army Engineer Research and Development Center (ERDC) under the purview of the Environmental Laboratory (EL). Funding was provided under the Department of Army Appropriation Number 96X3122, Construction General. In addition, funding for some of the earlier releases and monitoring was provided by the U.S. Army Corps of Engineers, Galveston District. The APCRP is managed under the Center for Aquatic Plant Research and Technology (CAPRT), Dr. John W. Barko, Director. Mr. Robert C. Gunkel, Jr., was Assistant Director for the CAPRT. Program Monitor during this study was Mr. Timothy Toplisek, HQUSACE.

Principal Investigator for this work unit was Dr. Alfred F. Cofrancesco, Aquatic Ecology Branch, Ecosystem Research Division (ERD), EL. This report was reviewed by Drs. Judy Shearer and Jack Kilgore. Dr. Michael J. Grodowitz, Dr. Cofrancesco, and Ms. Jan E. Freedman, all of ERD, and Dr. Ted D. Center, Aquatic Plant Research Facility, Fort Lauderdale, FL, prepared this report.

While in Texas the authors were assisted by many personnel from the Department of Texas Parks and Wildlife. The authors would like to especially thank Messrs. Mike Reed, Ray Cardona, and Mark Webb for their technical assistance.

This investigation was performed under the general supervision of Dr. C. J. Kirby, Chief, ERD, and Dr. John W. Keeley, Acting Director, EL.

At the time of publication of this report, Dr. Lewis E. Link was Acting Director of ERDC, and COL Robin R. Cababa, EN, was Commander. 
This report should be cited as follows:

Grodowitz, M. J., Freedman, J. E., Cofrancesco, A. F., and Center, T. D. (1999). "Status of Hydrellia spp. (Diptera: Ephydridae) release sites in Texas as of December 1998," Miscellaneous Paper A-99-1, U.S. Army Engineer Research and Development Center, Vicksburg, MS.

The contents of this report are not to be used for advertising, publication, or promotional purposes. Citation of trade names does not constitute an official endorsement or approval of the use of such commercial products. 


\section{Introduction}

The release of leaf-mining flies in the genus Hydrellia was begun in Texas in August 1991 with the introduction of $H$. balciunasi at Sheldon Reservoir (Grodowitz et al. 1997; Grodowitz and Snoddy 1992). Hydrellia balciunasi was initially chosen for release in Texas because of potential competition with $H$. pakistanae at Florida release sites and a closer match with the climate in Texas to that of its home range in Australia. After repeated attempts to establish $H$. balciunasi in Texas, with only limited success, it was also decided to release $H$. pakistanae. The first release of $H$. pakistanae occurred at Choke Canyon Reservoir in 1993 followed by releases in Coleto Creek Reservoir and Sheldon Reservoir (Grodowitz et al. 1997). Since the initial releases, over 300,000 individuals of both species of Hydrellia have been introduced at five locations, and populations of Hydrellia have now been discovered at sites in Texas where no known releases have occurred (Figure 1). ${ }^{1}$

\footnotetext{
1 Unpublished data, Dr. Michael J. Grodowitz, U.S. Army Engineer Research and Development Center, Vicksburg, MS.
} 


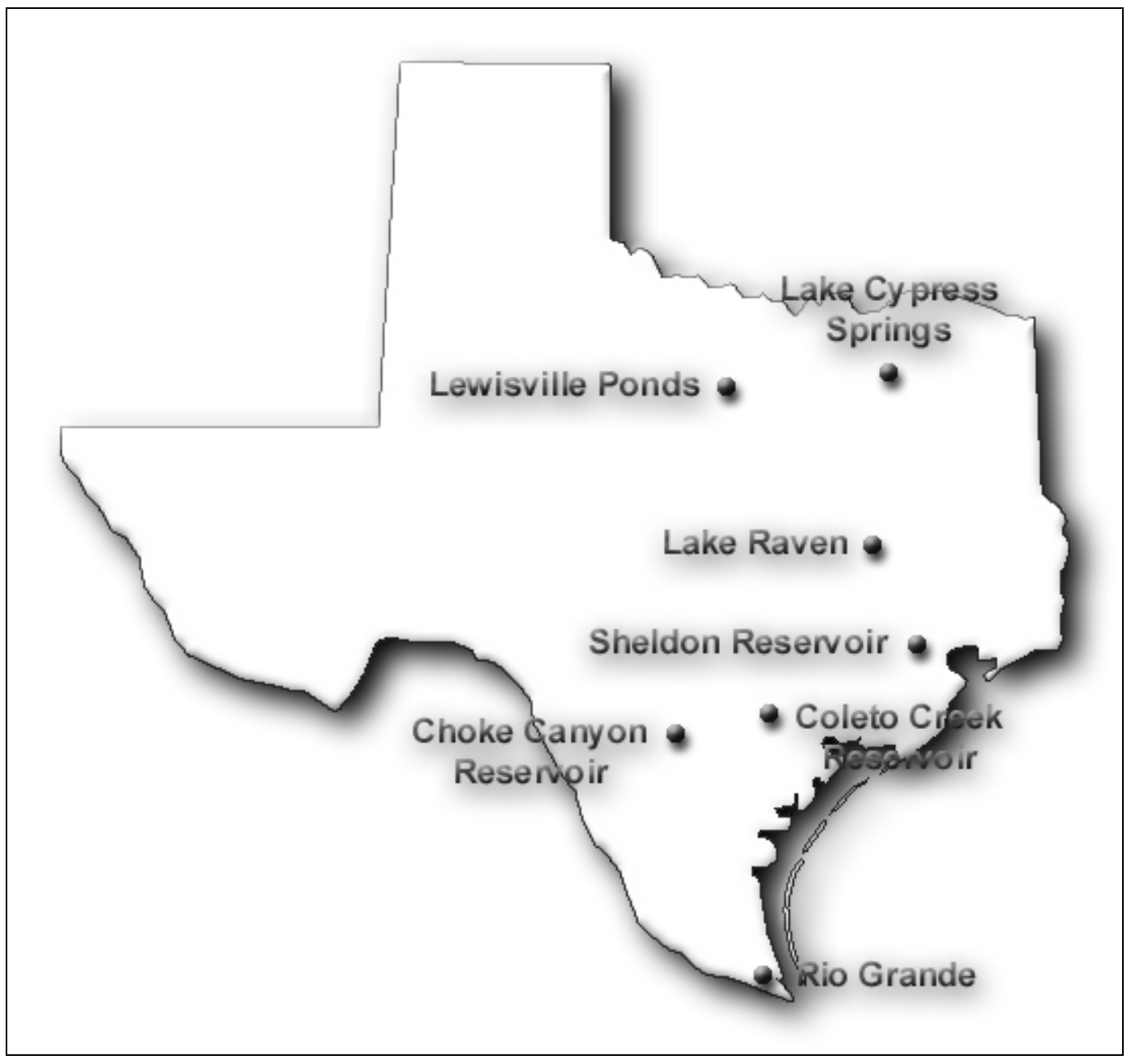

Figure 1. Map of Texas showing location of Hydrellia spp. release sites and additional sites where populations of Hydrellia spp. have been identified but no known releases occurred 


\section{Site Information}

The following is a short history and current status of Hydrellia spp. release sites in Texas as of December 1998. Information is also included on some additional sites where Hydrellia spp. have been discovered but no formal introductions were made.

\section{Sheldon Reservoir}

The Sheldon Reservoir release site is a small 3- to 4 -acre ${ }^{1}$ pond adjacent to the main body of Sheldon Reservoir. It has been almost completely covered with hydrilla since the late 1980s with minimal quantities of coontail, Eurasian watermilfoil, and American lotus located around the periphery of the hydrilla infestation. No significant changes in this plant composition have been observed since 1989 (Figures 2, 3, and 4).

Hydrellia balciunasi individuals were first released into Sheldon Reservoir beginning in August 1991 with over 70,000 immatures released (Grodowitz et al. 1997; Grodowitz and Snoddy 1992). Establishment was confirmed in October 1992 when low numbers of $H$. balciunasi were collected 4 months after discontinuing releases. A low but persistent number of individuals were observed over the next several years, but the population level never exceeded 1,000 immatures per kilogram wet plant weight and 15 percent of the leaves damaged. By the end of the 1995 growing season, only 100 immatures per kilogram and <1 percent of damaged leaves were observed. Because of declining insect numbers, failure of H. balciunasi to establish at other Texas and Florida locations, and no observable impact to the hydrilla infestation at this and other sites, it was decided to release H. pakistanae into the Sheldon Reservoir pond.

One release of close to 50,000 $\mathrm{H}$. pakistanae immatures was introduced at Sheldon Reservoir pond in 1995. Sampling during 1996 and 1997 confirmed that both leaf-mining fly species were established at low but persistent numbers. The H. pakistanae population was slightly larger by 1997 . There was still no observable impact to the hydrilla populations; i.e., the hydrilla infestation was essentially similar to what was observed in previous years.

1 To convert acres to hectares, multiply by 2.47 . 


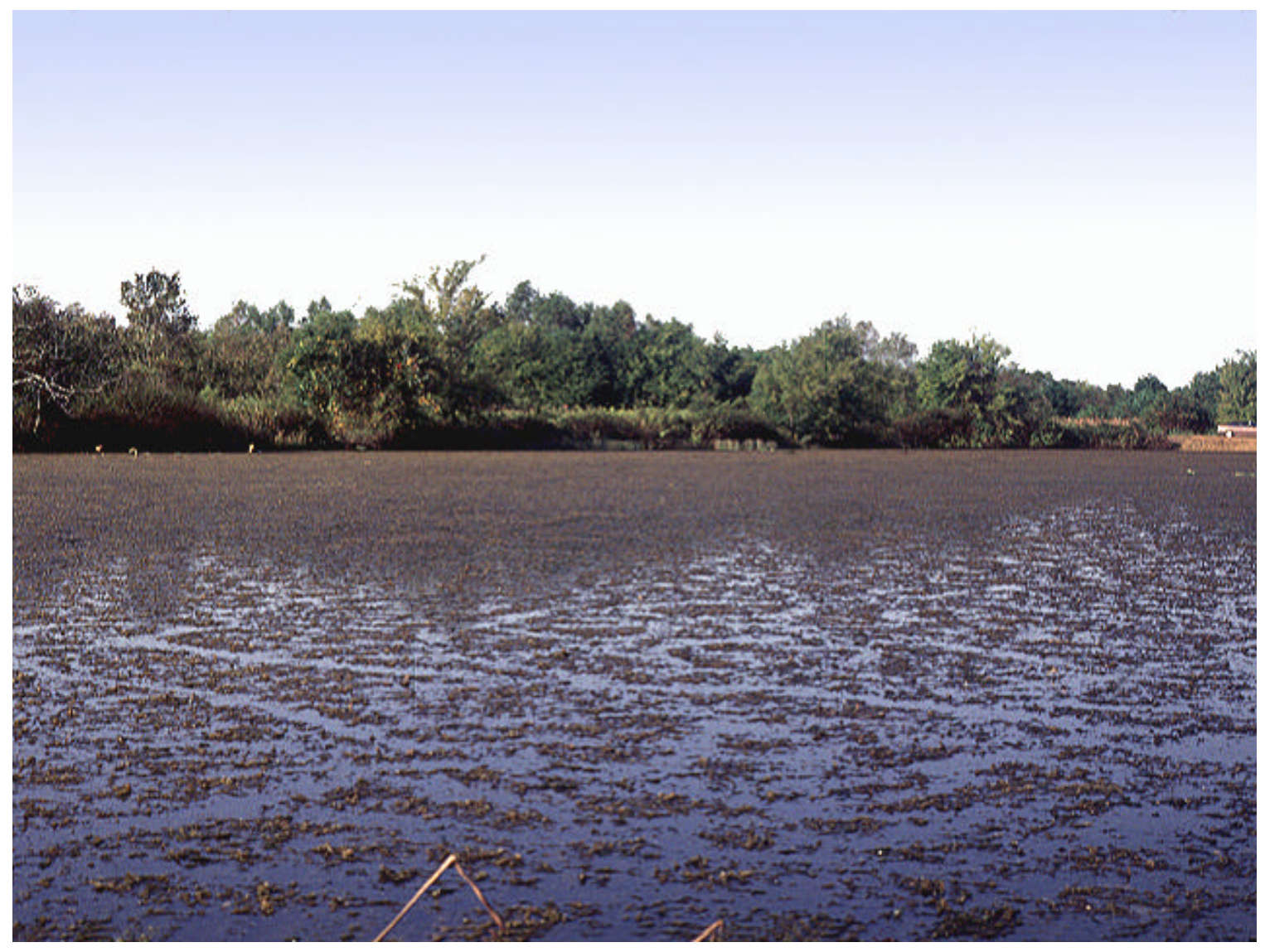

Figure 2. Sheldon Reservoir pond during October 1992 (Note dense stand of hydrilla throughout entire site. While not evident in photograph, there were limited quantities of coontail, Eurasian watermilfoil, and American lotus around periphery of infestation)

When the site was examined in September 1998, significant changes in the extent of the hydrilla population were observed (Figures 5, 6, and 7). Hydrilla did not cover a majority of the site, but instead was found scattered with coontail, Eurasian watermilfoil, and to some extent American lotus. A contiguous hydrilla monoculture was found in only one localized area.

During sampling of the site in September 1998, limited hand collection of adult flies yielded two $H$. balciunasi; the remaining 10 were native Hydrellia spp. No $H$. pakistanae adults were collected. Limited larval damage was noted in the field, and no damaged leaves or immatures were found in quantitative sampling. Berlese funnel extraction of the larvae revealed only 1.6 immatures per kilogram wet plant material. Since immatures cannot be reliably identified, it is uncertain if the collected immatures were the introduced species or one of two native Hydrellia species known to feed on hydrilla in limited numbers at field locations in Texas. 


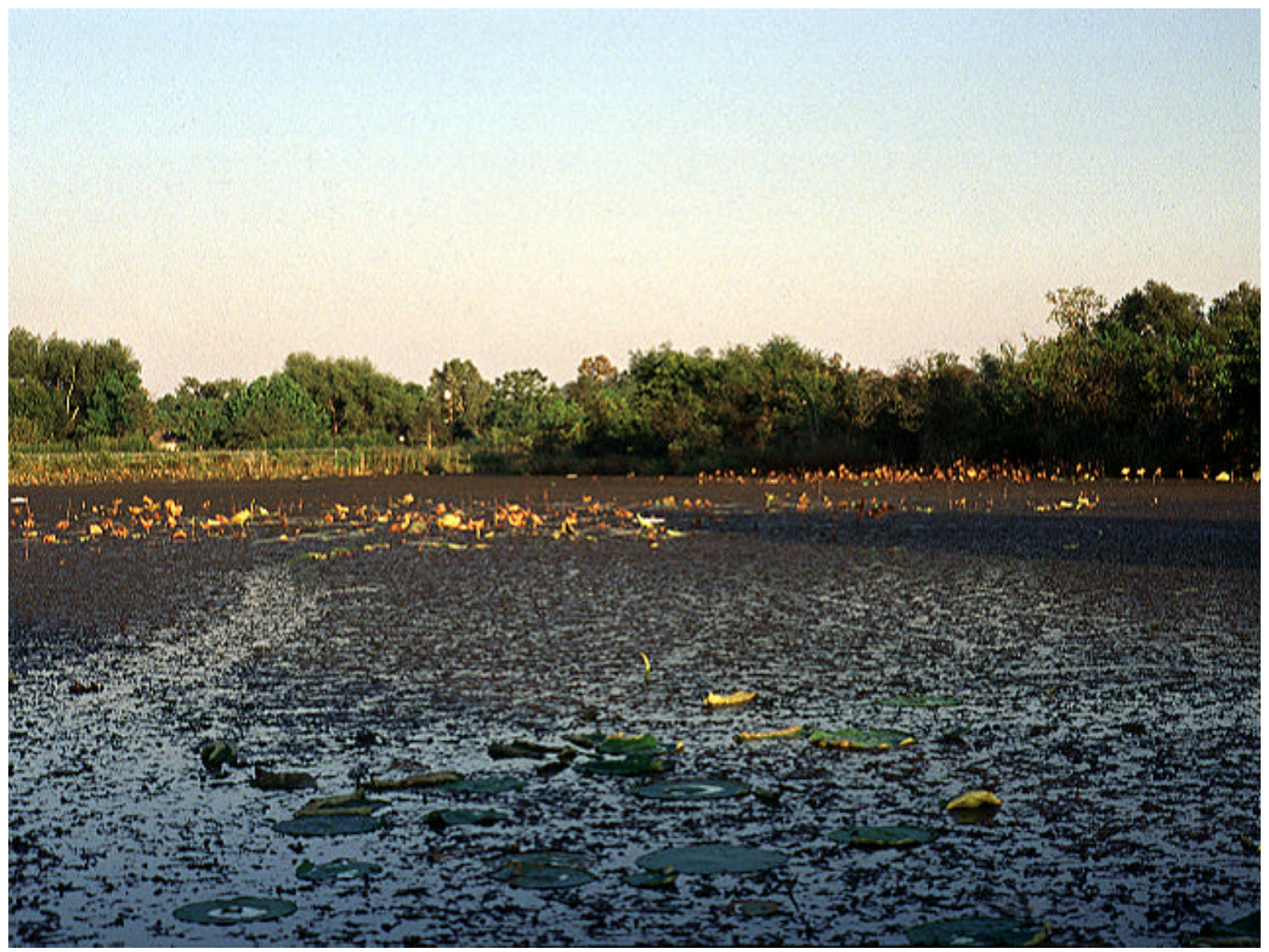

Figure 3. Sheldon Reservoir pond in September 1994 (Note dense hydrilla infestation with moderate levels of American lotus)

Reasons for the change in the hydrilla infestation at Sheldon Reservoir are unknown. Water levels dropped during a prolonged drought during 1996/1997, but this should not have caused the drastic decline in the hydrilla population, which actually fairs better in shallower water (Smart and Doyle 1995). Texas Parks and Wildlife Department personnel have suggested that a possible reason for the declines ${ }^{1}$ is feeding on the hydrilla by large numbers of coots during the winter of 1997/1998. However, such feeding would not be expected to reduce hydrilla to such low levels, especially over extended growing periods since coot impact is usually confined to the winter months. Since increases in Hydrellia numbers could not be documented at this site, insect herbivory cannot be cited as a plausible reason for the declines. However, little, if any, information is available on the impact of low levels of sustained insect herbivory on hydrilla, which could possibly alter the competitive ability of the plants.

\footnotetext{
${ }^{1}$ Personal Communication, 1998, Mr. R. Comstock, Sheldon Reservoir, Texas.
} 


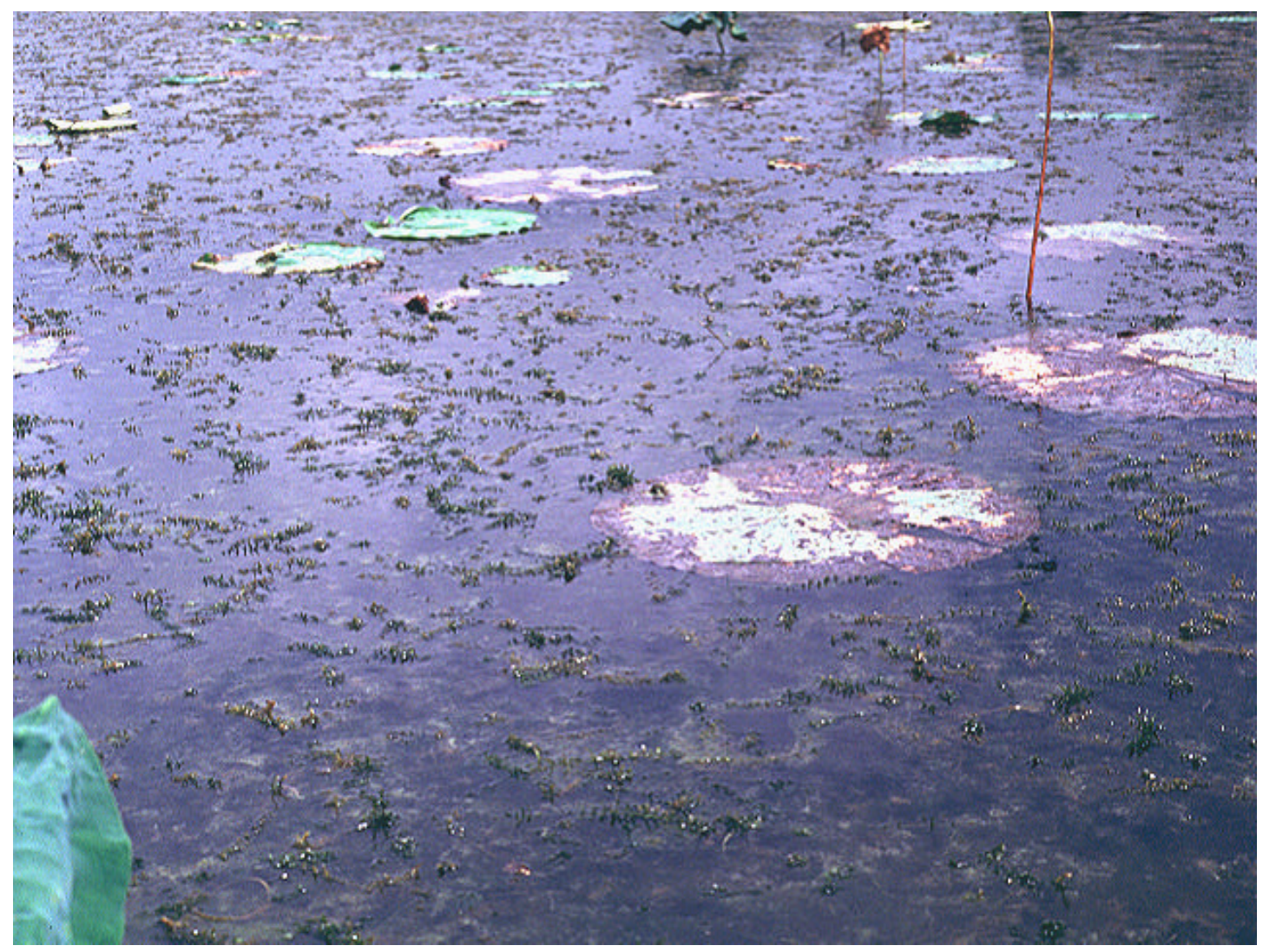

Figure 4. Close-up of hydrilla infestation on Sheldon Reservoir pond in September 1994 (Note dense hydrilla infestation with minimal presence of other submersed species)

\section{Huntsville State Park - Lake Raven}

Lake Raven is located within the boundaries of Huntsville State Park approximately $100 \mathrm{~km}$ north of Houston, TX. Hydrilla has been a problem at this lake since 1992. It is mainly confined to the shallow areas of the lake with more extensive infestations toward the end of several shallow coves (Figure 8).

Hydrilla has been persistent in these areas and forms a dense canopy at the water surface during the summer months.

Hydrellia balciunasi individuals were first released into Lake Raven beginning October 1992, and introductions continued through 1994/1995 (Grodowitz et al. 1997; Grodowitz and Snoddy 1992). In 15 separate introductions, over 75,000 immatures were released at several areas in the same general vicinity of the lake. Only minimal numbers of $H$. balciunasi were ever recovered at this site. The highest number of immatures was collected during the 1993 and 1994 growing seasons and never exceeded 175 immatures per kilogram wet plant weight and 1.6 percent leaves damaged. No additional immatures or adults were recovered during 1995 and 1996. 


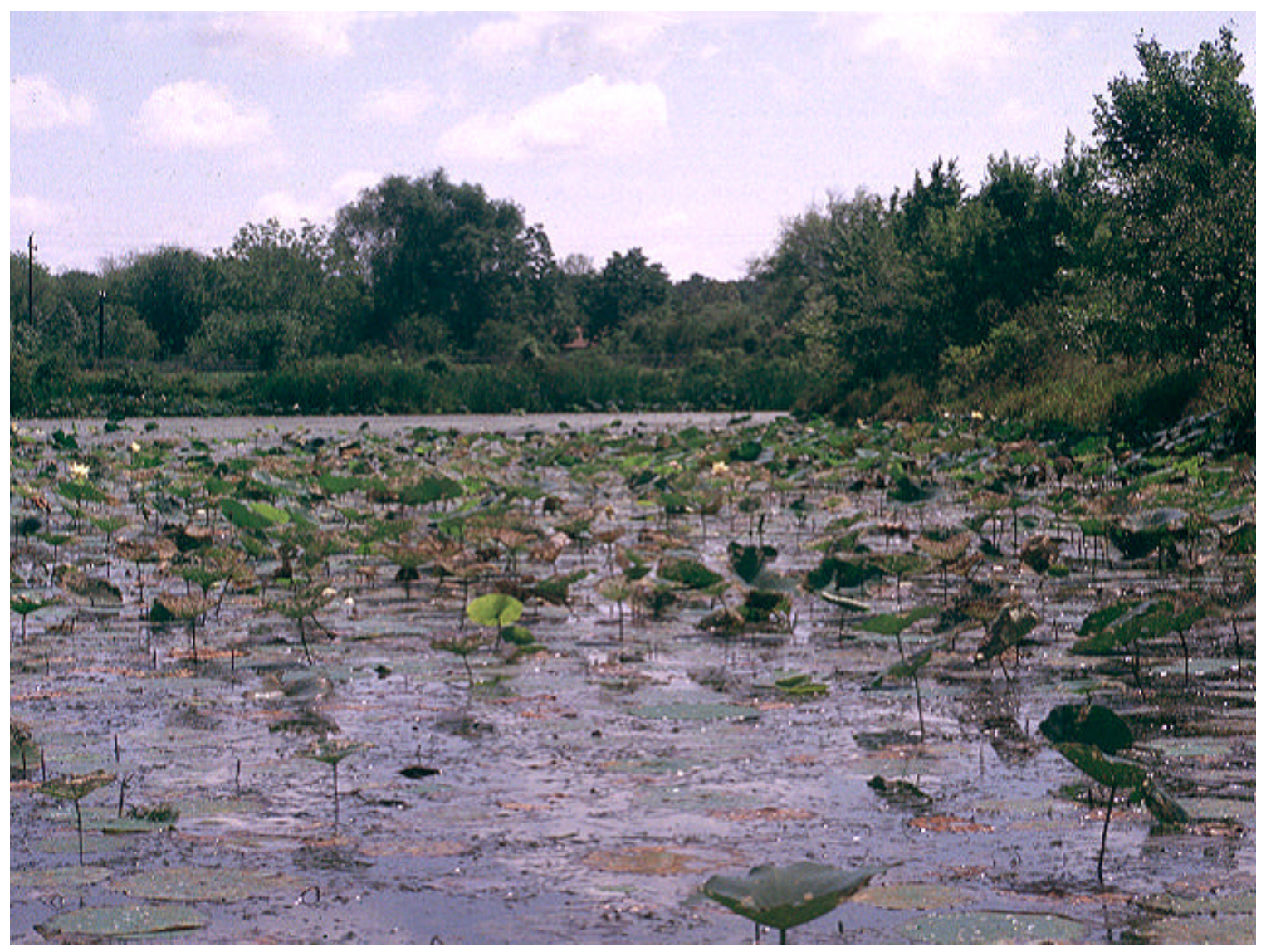

Figure 5. Sheldon Reservoir pond taken during September 1998 (While pond appears to be covered entirely by hydrilla, bulk of submersed vegetation is a mixture of hydrilla, Eurasian watermilfoil, and coontail)

Reasons for the disappearance of $H$. balciunasi from this site are unknown. While $H$. balciunasi has proven to be extremely hard to establish, once established it has persisted albeit at very low population levels (Grodowitz et al. 1997; Grodowitz and Snoddy 1992). Several reasons may have contributed to the disappearance of $H$. balciunasi on Lake Raven. These include high water levels removing hydrilla in the vicinity of the establishment during 1994 and a herbicide treatment that drifted from the target area and impacted a large portion of the hydrilla in the area of the establishment. Unfortunately, Lake Raven was not sampled during 1997.

Lake Raven was again surveyed during September 1998. At this time, noticeable changes were observed in the hydrilla in the area of the previous releases. The hydrilla was less dense with many portions of the mat not extending to the water surface (Figures 9, 10, and 11). Stem pieces that apparently had broken off from the rooted plants were found floating on the water surface. This impact was observed in many areas of the site. However, the hydrilla near some portions of the shore was in good condition, "topped-out," and relatively dense with no evidence of larval feeding and damage. 


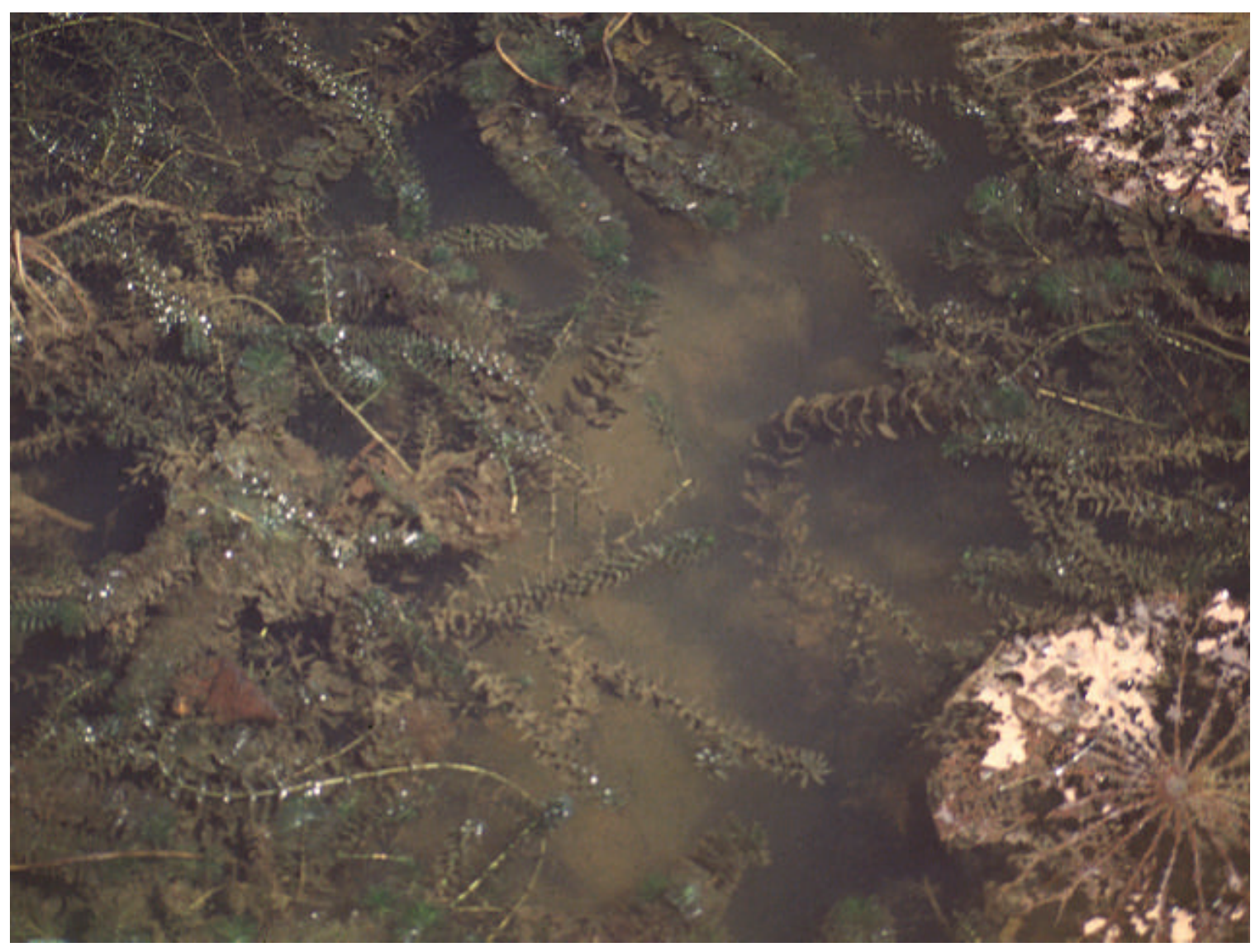

Figure 6. Close-up of submersed vegetation in Sheldon Reservoir pond (Note large holes in hydrilla canopy, less dense nature of infestation, and presence of several other species of submersed vegetation)

Considering that no flies were collected from the site during 1995, it is extremely interesting that in September 1998 a total of 23 adults were hand collected and 16 or 64 percent were $H$. balciunasi. Larval-feeding damage was routinely observed throughout the site. The number of immatures averaged 100 per kilogram wet plant material with an average leaf damage of about 1.0 percent. Of the 25 stems examined, 13 percent had some form of larval damage.

Again it cannot be said with certainty that the changes observed in the hydrilla at Lake Raven were due to fly feeding or to other abiotic and/or biotic factors. Mr. Mark Webb of the Texas Parks and Wildlife Department indicated that similar changes in hydrilla status were found at other portions of Lake Raven even though flies were never released in those areas. Unfortunately, other hydrilla infestations on Lake Raven were not checked for presence or absence of Hydrellia spp. during the September sampling trip. Hence, it is not certain if fly impact could have been a factor in those areas as well. 


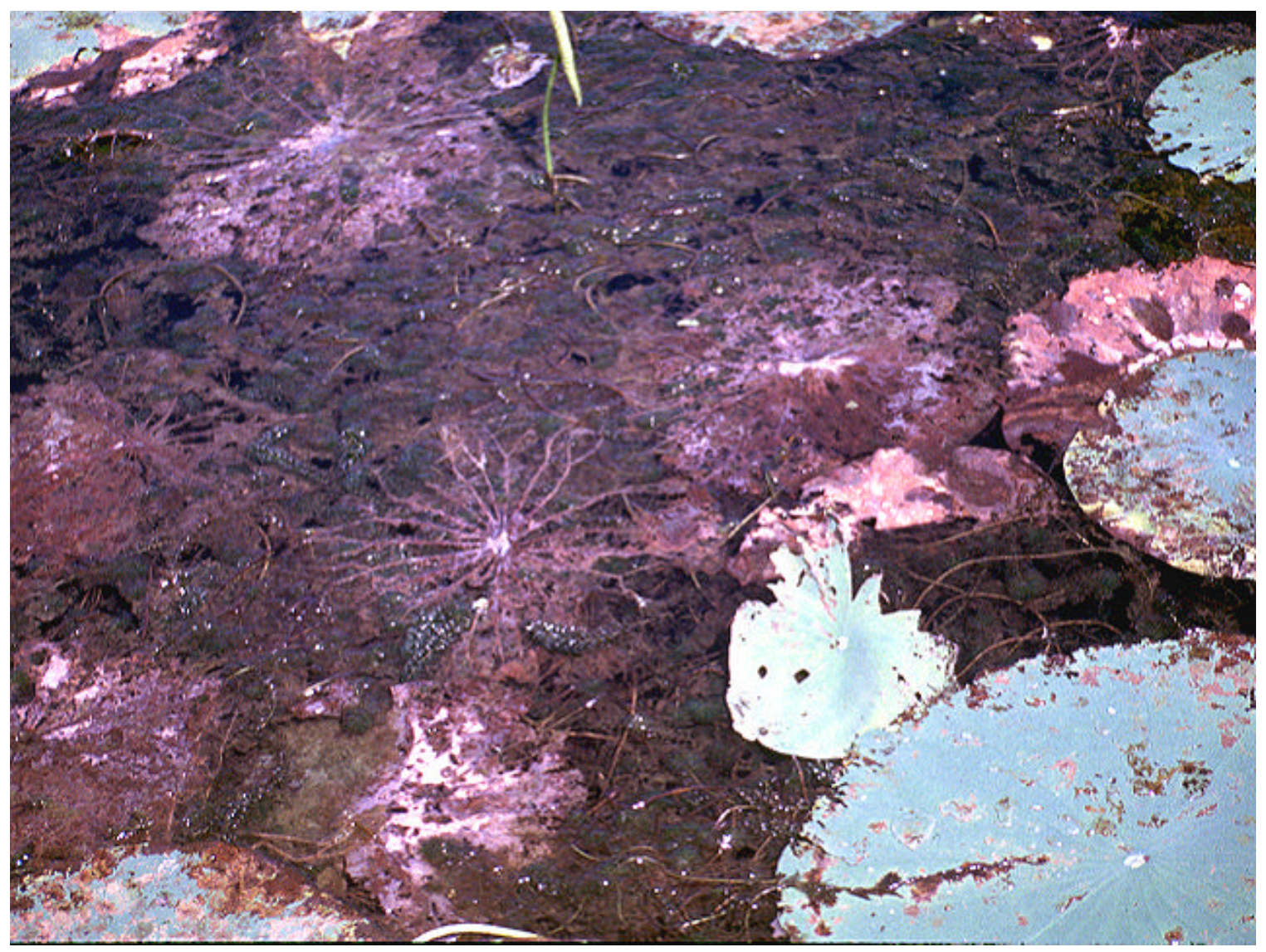

Figure 7. Close-up of submersed vegetation in Sheldon Reservoir pond (Hydrilla was much reduced in this area with other species of vegetation, especially coontail and Eurasian watermilfoil, present in high quantities)

It is important to note that while fly populations were low at Lake Raven during September 1998, over 13 percent of stems examined had at least some feeding damage. Larvae feed on from 9 to 12 leaves in close proximity to one another during their developmental cycle (Buckingham, Okrah, and Thomas 1989). Such concentrated feeding on the leaf whorls the stem at the nodes, and it breaks off relatively easily from the plant. ${ }^{1}$ Floating pieces of stems were commonly observed at the Lake Raven release site. If the stems had broken off because of fly feeding, this could account for the numerous areas of the hydrilla mat where the plants were not "topped-out" and resided below the surface of the water.

Another important facet of Hydrellia spp. biology is that Hydrellia spp. can be very localized within a single body of water and that high numbers can exist in only certain areas, areas not being sampled regularly because of the random

\footnotetext{
1 Unpublished observations, Dr. Michael J. Grodowitz, U.S. Army Engineer Research and Development Center, Vicksburg, MS.
} 


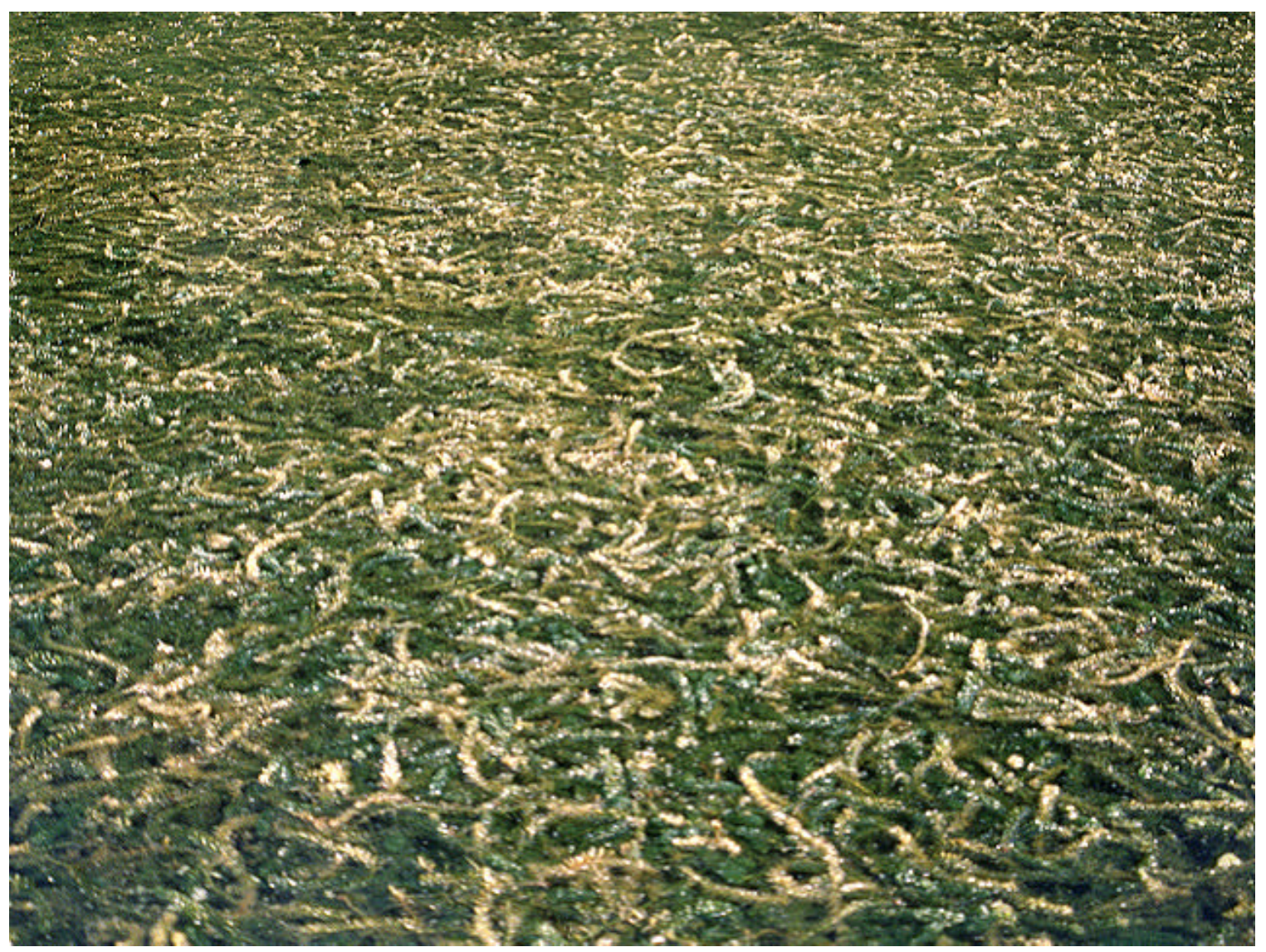

Figure 8. Close-up of submersed vegetation at Lake Raven release site during August 1994 (Note dense mat of hydrilla at or close to water surface with no obvious breaks in infestation)

selection process. ${ }^{1}$ For example, at Lake Raven, three samples were taken within $45 \mathrm{~m}$ of each other. In one sample, no larval damage or immatures were found. The next sample had an average leaf damage of 0.2 percent with immature levels of close to 100 immatures per kilogram wet plant weight, while the third sample had a leaf damage of 2 percent with immature populations of over 200 immatures per kilogram. Such clumped distributions are very common for this species and only make it more difficult to accurately assess population size and impact. High and damaging Hydrellia spp. populations could be confined to only one small area and potentially not be located anywhere near the original release site. This may be especially important during the first few years after initial establishment has occurred and populations are just beginning to increase and expand into other areas. A higher number of samples should be taken at greater frequency for each site examined.

\footnotetext{
1 Unpublished data, Dr. Michael J. Grodowitz, U.S. Army Engineer Research and Development Center, Vicksburg, MS.
} 


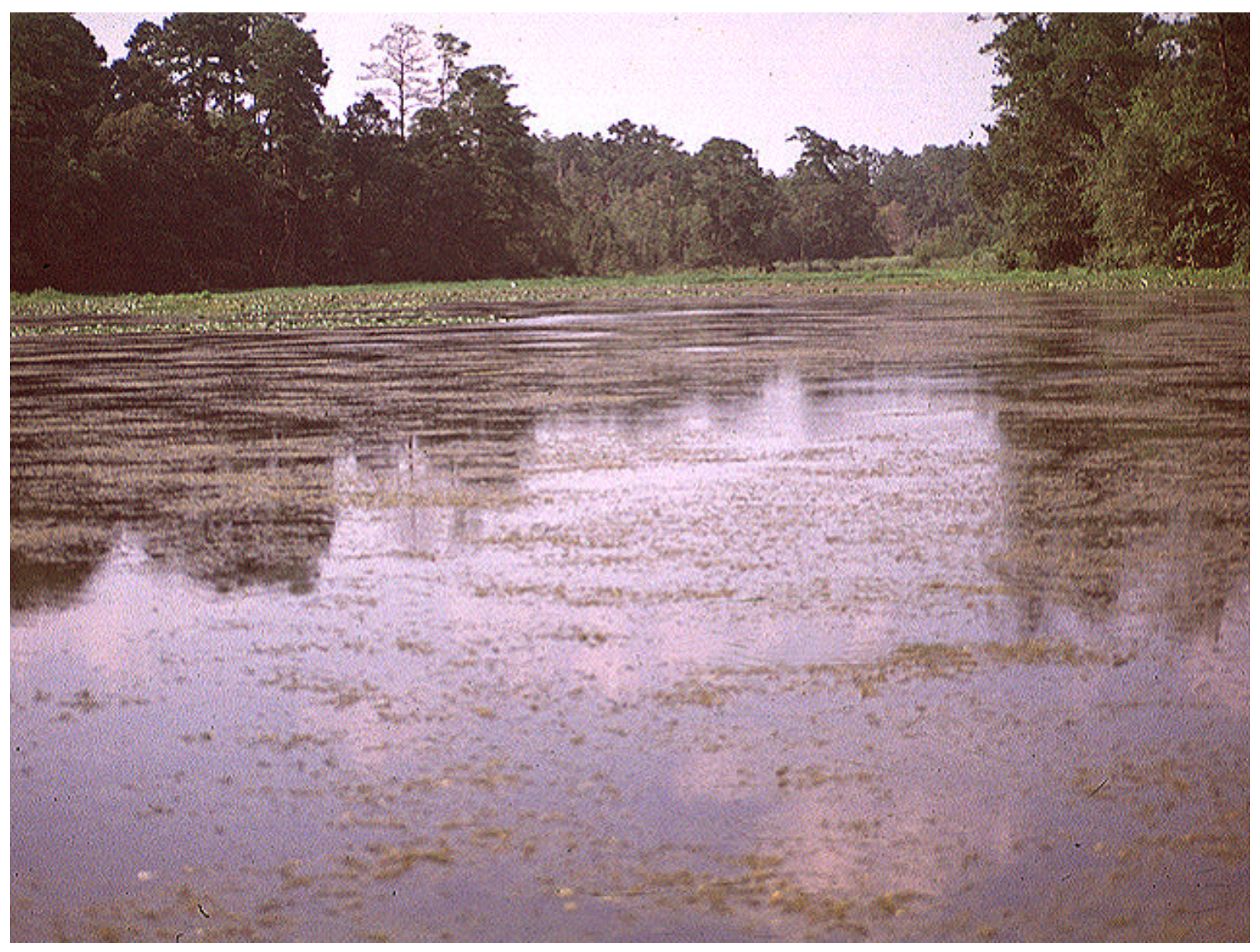

Figure 9. Lake Raven Hydrellia balciunasi release site during September 1998 (While a majority of site appears covered with hydrilla, note that in some areas hydrilla has not extended entirely to surface)

\section{Coleto Creek Reservoir}

Coleto Creek Reservoir located about $30 \mathrm{~km}$ west of Victoria, TX, is a 3,100acre impoundment located in the Guadalupe River drainage. The lake has had hydrilla problems for several years with the hydrilla mainly confined in the shallower areas near the shoreline (Figures 12 and 13).

Beginning in December 1992 and continuing through May 1993, over 33,000 H. balciunasi were released into two areas (i.e., the cove and dam release site) on Coleto Creek Reservoir in 11 separate introductions (Grodowitz et al. 1997; Grodowitz and Snoddy 1992). Following the initial introductions during 19921993, examination of the site in spring 1993 indicated possible establishment based on the observation of larval-feeding damage. However, following the spring 1993 sampling, no further damage was observed, and no adult Hydrellia spp. were collected. This prompted continued releases with the more successful H. pakistanae in June 1994 (Center et al. 1997). 


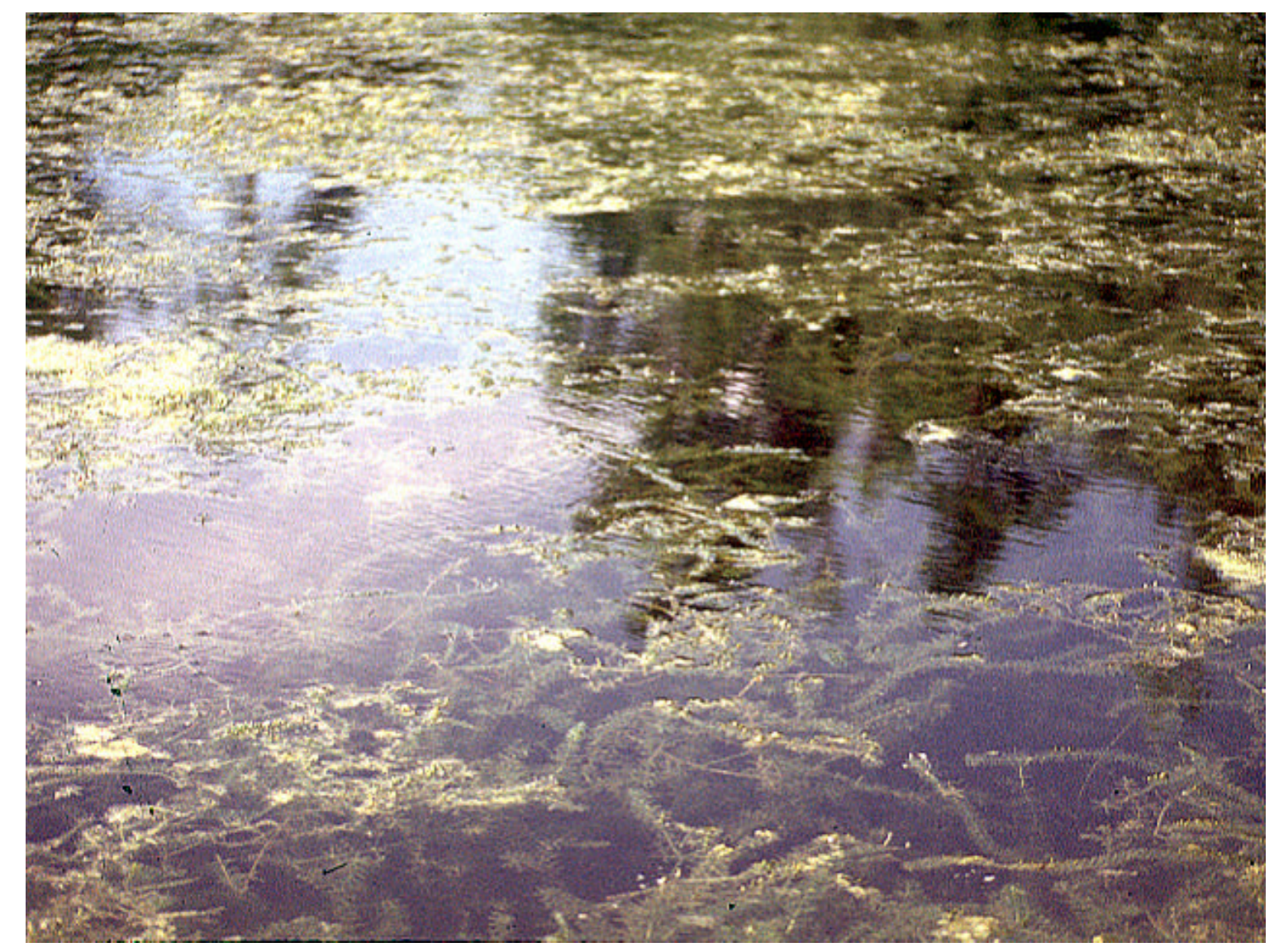

Figure 10. Close-up of submersed vegetation in Lake Raven Hydrellia balciunasi release site during September 1998 (Note holes in hydrilla canopy and less dense nature of infestation)

Beginning in June 1994 and continuing through 1995, more than 30,000 $\mathrm{H}$. pakistanae were released into two separate locations (i.e., the cove and dam release site) on the reservoir (Center et al. 1997). Establishment was confirmed in 1996 with collection of adult $H$. pakistanae and the presence of larval damage at the original release sites and upwards of $1 \mathrm{~km}$ away. Similar collection of adults, immatures, and observation of larval-feeding damage were noted again in 1997. The hydrilla at the cove release site, when examined during July 1997, appeared to be somewhat reduced in comparison with past years, but only limited numbers of adults and immatures were collected. At the time, this seemed to indicate that other factors were responsible for the reductions in hydrilla and were not caused by $H$. pakistanae feeding damage.

Sampling conducted during late August 1998 revealed a large and flourishing population of $H$. pakistanae at Coleto Creek Reservoir, especially at the two original release sites. Hydrilla collected at the cove site had leaf damages of greater than 5 percent and an immature population of close to 500 immatures per kilogram. Of the 25 stems examined for leaf damage and number of immatures, over 80 percent of the stems had some form of damage. This may have 


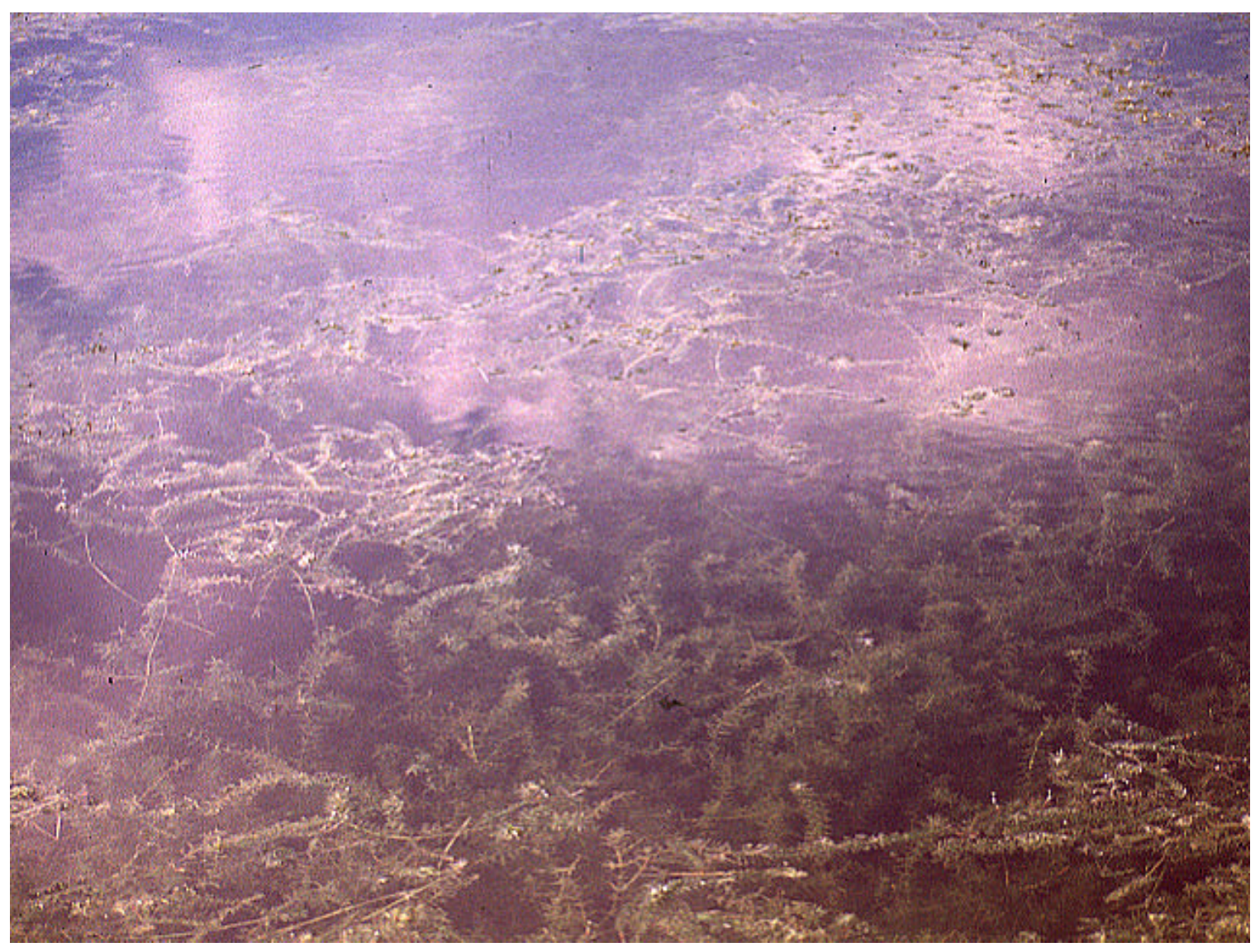

Figure 11. Close-up of submersed vegetation in Lake Raven Hydrellia balciunasi release site during September 1998 (Note how hydrilla, while present, has not reached surface in many areas and presence of broken stems floating on water surface)

contributed to the low quantity of hydrilla (ca. 85 percent reduction in comparison with 1994) that had reached the water surface since many of the stems may have broken off at the nodes where feeding damage on the whorls was high (Figures 14 and 15). This is in contrast to 2 years prior where a majority of the site, especially near the shoreline, had large amounts of very dense, topped-out hydrilla (Figures 12 and 13).

The Coleto Creek Reservoir release site adjacent to the dam was also examined during September 1998. In previous years, this site was covered with a large, dense infestation of hydrilla. In fall 1998, the hydrilla was decidedly less dense, and a canopy had not formed at the water surface (Figures 16 and 17). A large mat of filamentous algae covered the area; but when the algae was removed, most of the water surface was devoid of topped-out hydrilla. The hydrilla that was present had larval-feeding damage in relatively high quantities (>9 percent of the leaves damaged), and stems were more easily broken in areas where feeding damage was high. Immature numbers were close to 900 immatures per kilogram wet plant weight. Of the stems examined, $>75$ percent had at least some feeding damage. Adult flies were also collected at all three 


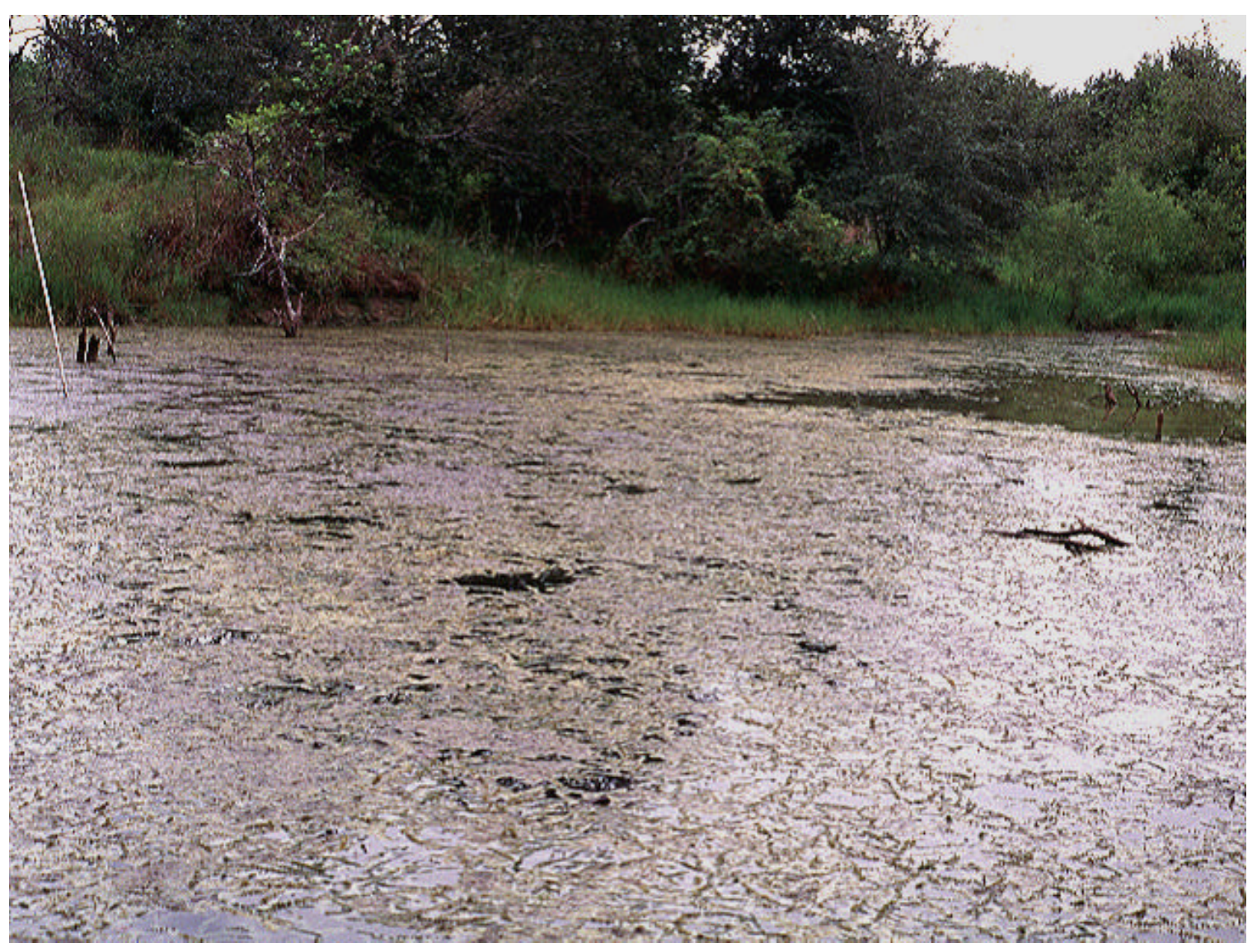

Figure 12. Coleto Creek Reservoir original cove release site during August 1994 (Note large quantity of hydrilla that has formed a dense canopy at water surface)

sites (i.e., the two release sites and one nonrelease area). This qualitative method of adult collection yielded a total of 41 flies, all of which were $H$. pakistanae. This included 24 males and 17 females.

The last site examined for presence/absence of $H$. pakistanae on Coleto Creek Reservoir was about $1 \mathrm{~km}$ north of the cove release site. No releases were ever conducted in this area. At this site, the hydrilla appeared in very good condition, dense and fully topped-out (Figure 18). As could be expected, the percentage of feeding damage was lower than what was found at either the cove or dam release areas (ca. 1 percent) with only 20 percent of the stems examined containing some form of larval-feeding damage. Immature numbers were only slightly greater than 200 immatures per kilogram. The hydrilla at this site is representative of what the hydrilla looked like at both the cove and dam release areas prior to the introduction of Hydrellia spp.

Of all the release sites visited, the impact observed to the hydrilla at the cove and dam release areas at Coleto Creek apparently was caused at least partially by the feeding action of the flies. The presence of relatively large numbers of immatures, high percentage of leaf damage, and high percentage of randomly 


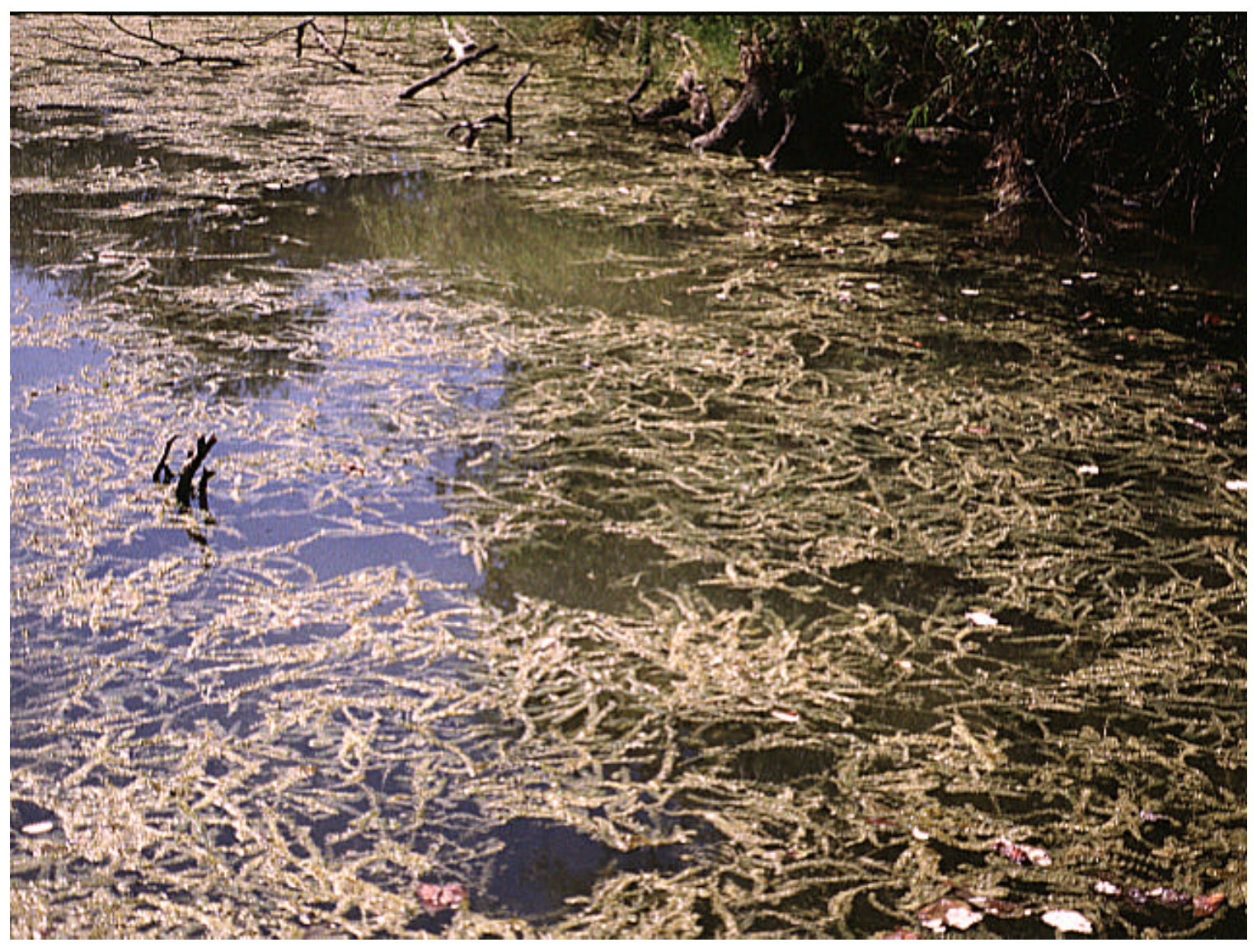

Figure 13. Close-up of original Coleto Creek Reservoir cove release site during September 1994 (Note dense infestation of hydrilla with little break in surface canopy)

collected stems having some form of feeding damage points toward this conclusion. In addition, the one site examined with only limited $H$. pakistanae populations had high-quality hydrilla that had formed a full canopy and had no obvious signs of stress.

\section{Choke Canyon Reservoir}

Choke Canyon Reservoir is a large 26,000-acre lake approximately $80 \mathrm{~km}$ south of San Antonio, TX. Hydrilla has been a consistent problem on the lake for many years with hydrilla confined mainly along the lake periphery. The site underwent a drastic reduction in water level during the years Hydrellia spp. introductions were being made because of a large-scale drought and the removal of water from Choke Canyon Reservoir to replenish water lost from Lake Corpus Christi. It is believed that the reduction in water level virtually removed all hydrilla in the lake by 1996. The reservoir first started refilling during 1997 and was close to 1993 levels by 1997/1998. 


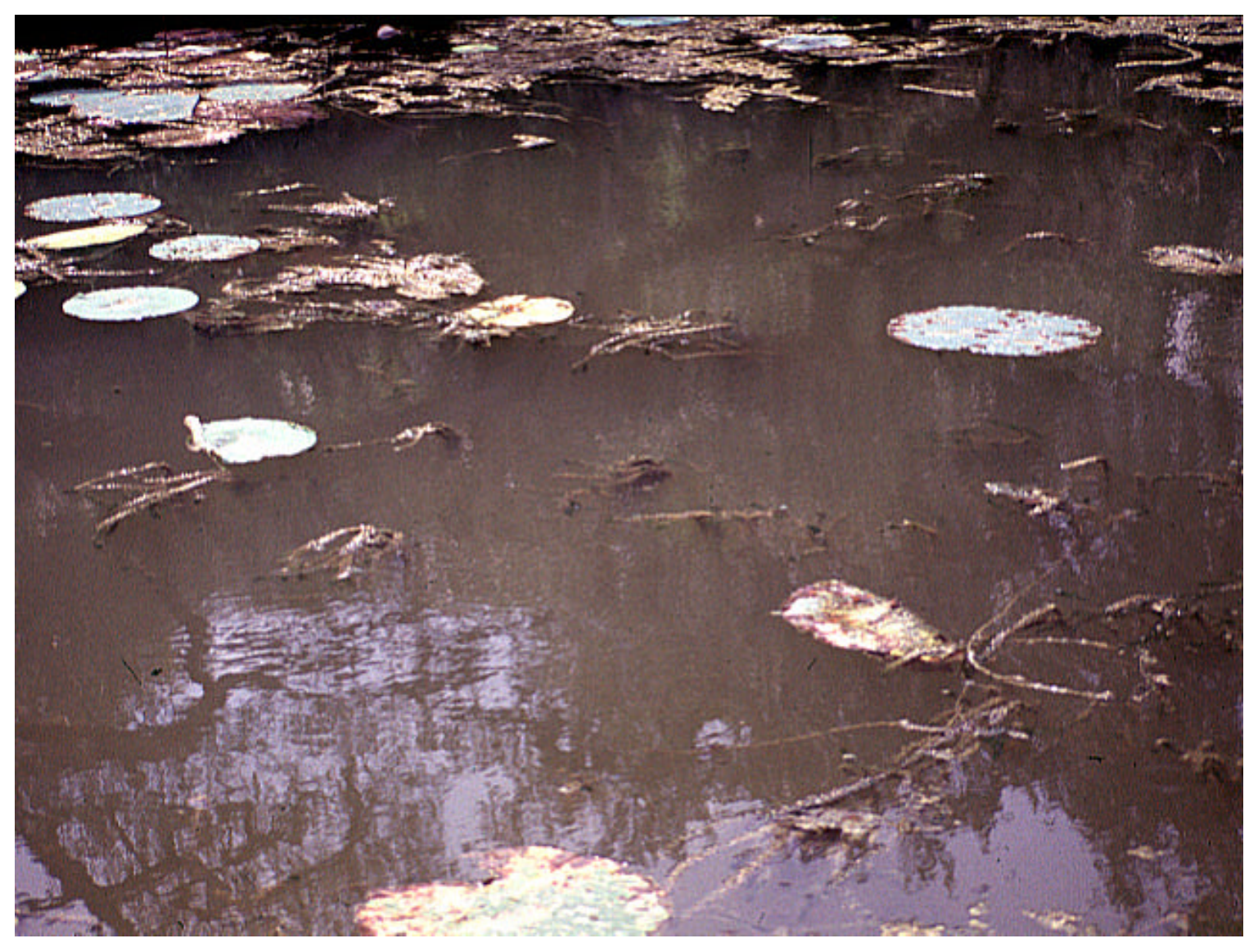

Figure 14. Close-up of original Coleto Creek Reservoir cove release site during September 1998 (There is little hydrilla remaining at this area with only a few scattered stems reaching water surface)

The authors first visited the site in 1992, and introductions of $H$. balciunasi began in 1993 (Grodowitz et al. 1997). Over 60,000 immatures were released over the next several years. Hydrellia pakistanae were also released at this site beginning in 1993 and continued through 1995 with over 100,000 individuals released (Center et al. 1997). No feeding damage or adults of the introduced Hydrellia spp. were ever recovered from Choke Canyon between 1992 and 1995. With the disappearance of the hydrilla from the site, further monitoring for Hydrellia spp. was discontinued for 1996 and 1997.

With the reinvasion of hydrilla during 1997/1998, Choke Canyon was revisited. Examination of the site revealed the presence of $H$. pakistanae adults, larval-feeding damage, and immatures. Distribution of the flies was very patchy with higher numbers present in some locations. The first two areas examined had very low feeding damage and a very low number of immatures. Leaf damage averaged, for these two areas, $<0.5$ percent and about 34 immatures per kilogram wet plant material. These two sites were adjacent to the original release area. This original release site was still dry from low-water levels and could not be sampled. The next area inspected was further removed from the first two but 


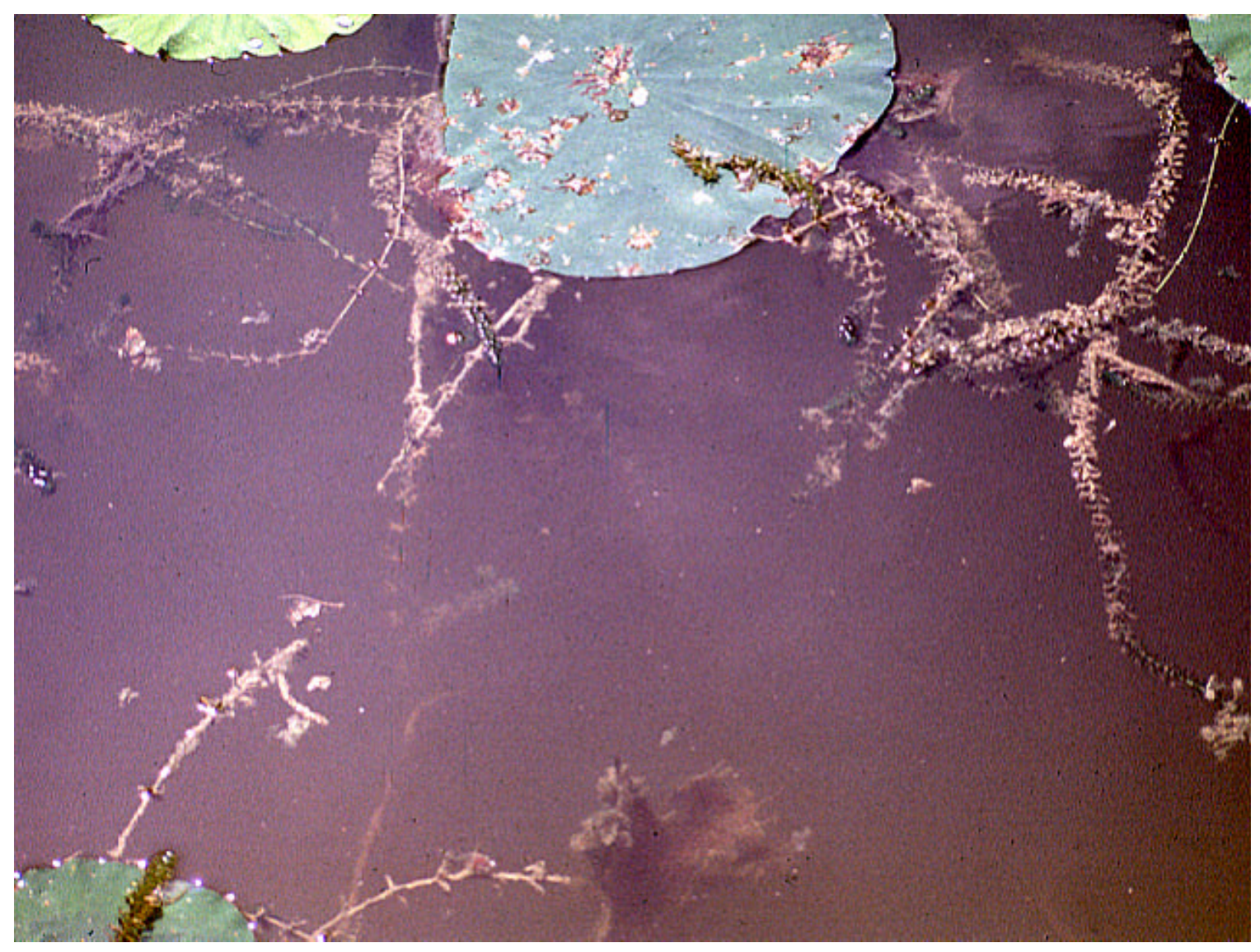

Figure 15. Close-up of original Coleto Creek Reservoir cove release site during September 1998 (Note how there are only a few scattered stems reaching water surface. Of remaining stems, over 80 percent had at least some immature Hydrellia leaf damage)

contained higher numbers of immatures and leaf damage. In this area, 64 percent of the stems examined had larval feeding damage; close to 4 percent of the leaves were damaged; and there were almost 500 immatures per kilogram of wet plant material. The hydrilla may have been somewhat less dense in the third area, but the differences in hydrilla status were hard to distinguish qualitatively from the first two areas examined.

How $H$. pakistanae survived during the period when low-water levels essentially removed the hydrilla from the system is unknown. A small pond off the main body of Choke Canyon had a substantial hydrilla infestation during the period of water loss. This site has never been examined for presence of $H$. pakistanae and may have been the source for recolonization in the main body of Choke Canyon. Hydrellia spp. may have been reintroduced to the site after the hydrilla returned. This is unlikely since the hydrilla had only returned to the lake since 1997 and the closest $H$. pakistanae-established site is about $100 \mathrm{~km}$ east of Choke Canyon. The relatively high population of Hydrellia spp. at some Choke Canyon areas indicates that they have been present for at least 1 to 


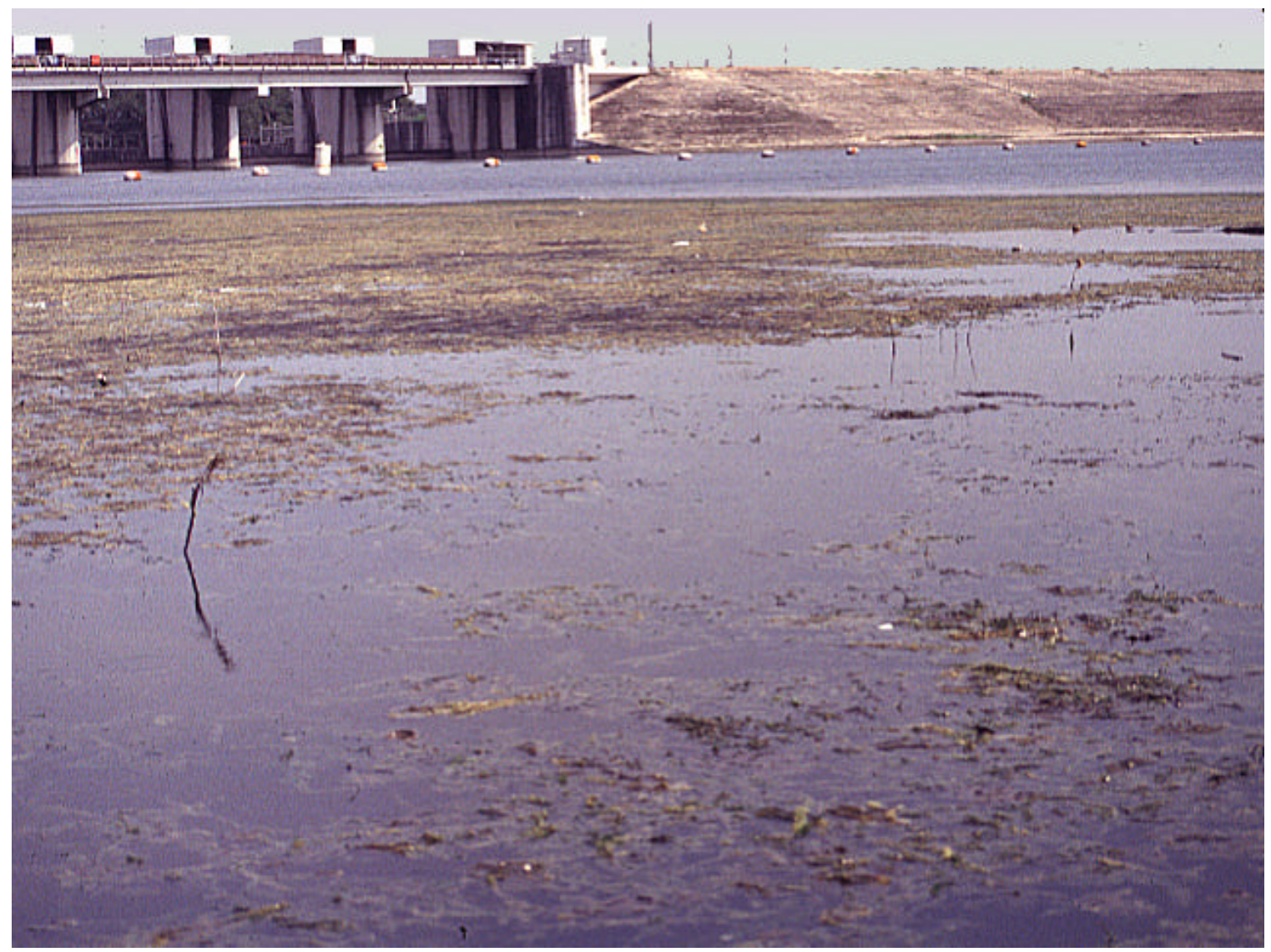

Figure 16. Coleto Creek release site adjacent to dam, August 1998 (While hydrilla appears to be fully topped out, note how some of area seems devoid of hydrilla)

2 years. This discovery is especially interesting since establishment of H. pakistanae was never confirmed in Choke Canyon prior to 1998. In any case, it appears $H$. pakistanae is well established at this site; if hydrilla infestations continue in Choke Canyon, the fly populations should persist and possibly expand.

\section{Rio Grande - Brownsville}

The Rio Grande is a riverine system that has recently been observed to have expanding hydrilla population. While this is the first year that hydrilla has been cited as a major problem in the Rio Grande, the large extent of the hydrilla infestations along the river indicates it has been present for some time. The hydrilla is quite dense on the river, and many of the examined locations had hydrilla populations with unusually long stems. This is curious since average depth of the river is below $1.5 \mathrm{~m}(5 \mathrm{ft})$. However, because of the small but steady water flow within the Rio Grande, the hydrilla tends to trail out into the current, hence reaching lengths greater that the average depth in many places. 


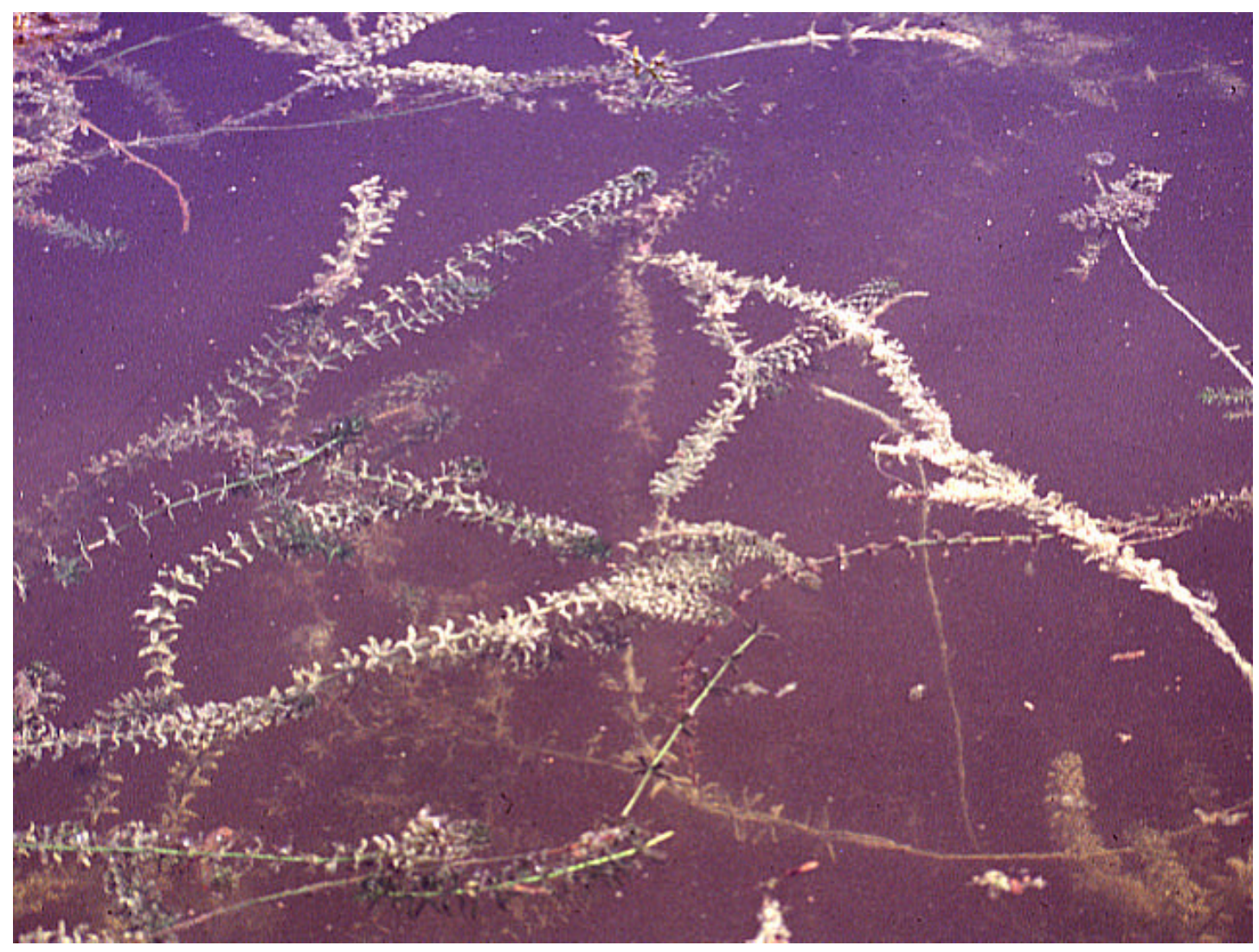

Figure 17. Close-up of hydrilla at "dam" Coleto Creek release site during August 1998 (Note how hydrilla is less dense with only a few stems reaching water surface. This lack of hydrilla density creates effect of holes forming in canopy)

During late October 1998, several areas on the Rio Grande near Browns ville, TX, were examined for presence of Hydrellia spp. and associated damage. Hand collection of adults at several locations on the river yielded nine females and four males. Approximately 1.2 percent of the leaves were damaged, and immature numbers were about 160 immatures per kilogram of wet plant material.

While these numbers indicate a low population of $H$. pakistanae in this area, this is very surprising since no $H$. pakistanae have been released within $400 \mathrm{~km}$ of Brownsville, TX. The closest release site is Choke Canyon Reservoir located about $300 \mathrm{~km}$ northwest of Brownsville. More importantly, there are no other large water bodies between Brownsville and Choke Canyon containing major hydrilla infestations. How this fly has come to be established on the Rio Grande is unknown. Adult colonization appears unlikely since this species has poor flying ability and the adult life span of ca. 10 days is not long enough to allow individuals to reach such extended distances. The only plausible explanation appears to be transportation of hydrilla that already contained $H$. pakistanae immatures. However, with only limited numbers of sites in Texas with confirmed Hydrellia spp. establishment, this explanation has only limited credibility. It has been suggested that strong winds may have transported the adults across the large distances. 


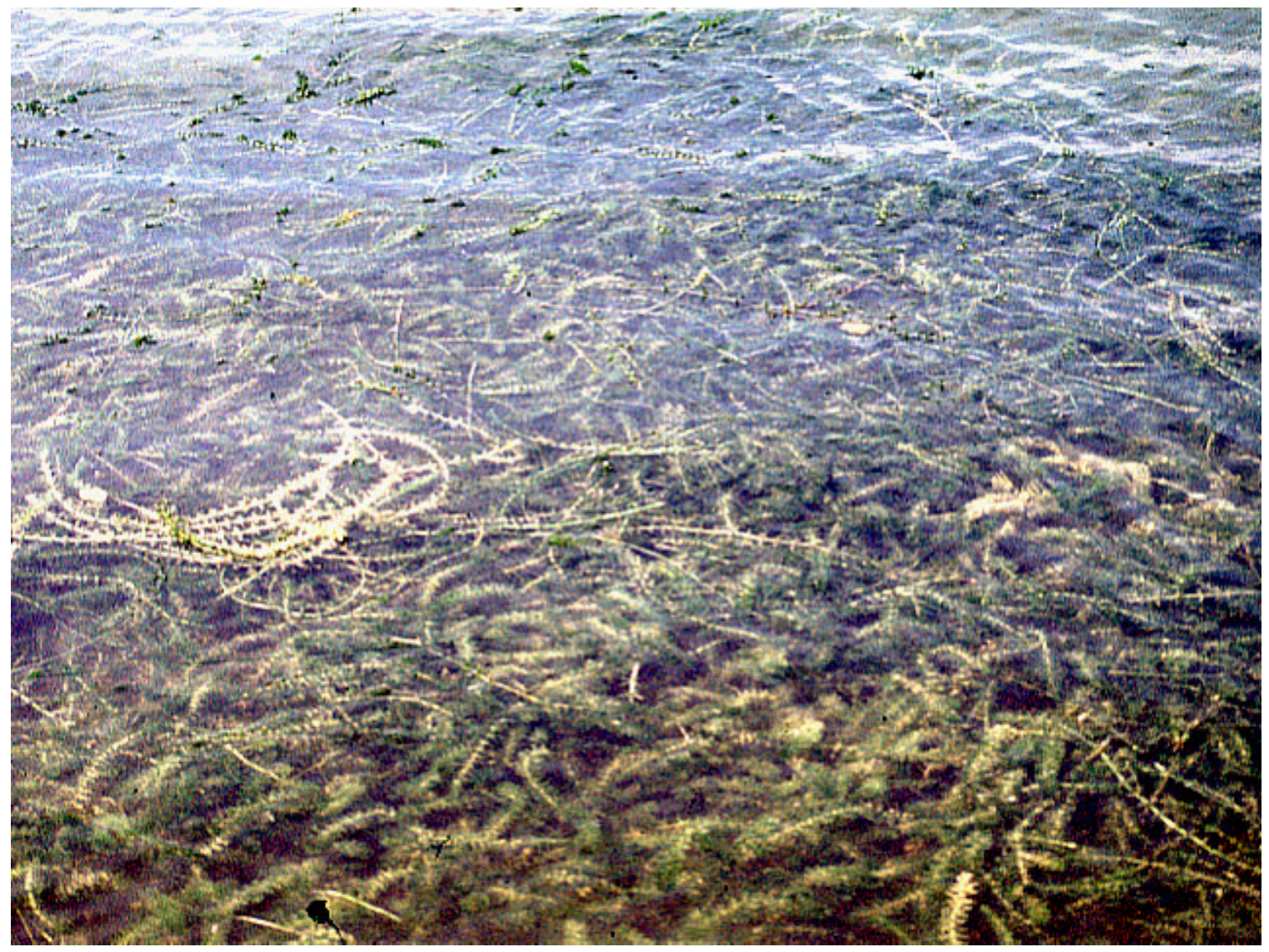

Figure 18. Close-up of hydrilla approximately $1 \mathrm{~km}$ upstream of original cove release site on Coleto Creek Reservoir during August 1998 (Fly populations at this site were low with feeding damage of about 1 percent and only 20 percent of stems examined containing some form of larval feeding damage. Note how hydrilla has formed a complete canopy with only minimal openings)

\section{Lake Cypress Springs}

Lake Cypress Springs is a small lake located north of Interstate 20 between Shreveport, LA, and Dallas, TX, near the town of Mount Vernon, TX. Hydrilla has been a reported problem on this lake for several years. The hydrilla appears to be mainly located in the shallower regions of the lake near the shoreline and cove areas.

During 1996, the Franklin County Water District and the Texas Parks and Wildlife Department contracted the U.S. Army Engineer Waterways Experiment Station (WES) to introduce H. pakistanae immatures into Lake Cypress Springs. Beginning in midgrowing season 1997 and continuing through fall 1997, close to 10,000 immatures were released into the Mary King area on Lake Cypress Springs. 
During late October 1998, several areas on Lake Cypress Springs were surveyed for presence of Hydrellia spp. These samples are still being processed, but preliminary observations indicate that $H$. balciunasi and not $H$. pakistanae is established on the lake. Populations are low but definitely present and occur across a wide area of the lake. Leaf damage and immatures were detected in low numbers in both qualitative observations and quantitative sampling of stem pieces.

It is highly unusual that $H$. balciunasi is established in this lake. This species was not purposely introduced into Lake Cypress Springs, and thus the question arises regarding how it got established. The first possibility is that it colonized from nearby sites. The closest established population of $H$. balciunasi is in Lake Raven in Huntsville State Park about $250 \mathrm{~km}$ to the south; hence, it seems highly unlikely that this species could have been introduced into Lake Cypress Springs from other locations. Hydrellia spp. is a relatively weak flyer and has been hard if not impossible to establish at many locations in Texas and Florida even with concerted efforts. Another possibility is that it may have been released as a contaminate with the H. pakistanae individuals released into this system in 1997. However, this also is highly unlikely since both Hydrellia species have not been in colony at WES for at least 3 years. The only other possibility is that hydrilla was introduced into Lake Cypress Springs from sites with established populations of $H$. balciunasi. However, again this would be highly unlikely since the number of sites in Texas with established populations is minimal (only two confirmed locations), and at those sites $H$. balciunasi populations exist at much reduced levels.

\section{Lewisville Aquatic Plant Facility}

Recently, ponds planted with hydrilla at the Lewisville Aquatic Ecosystem Research Facility (LAERF) were examined for the presence of Hydrellia spp. LAERF has been used over the last several years for various aquatic plant research activities. The ponds range from one-half acre to several acres in size. No formal introductions of Hydrellia spp. have been made into ponds at this facility. The only introductions were made in August 1998 into enclosed tanks as part of a plant competition/insect biological control experiment.

Observations on five of the ponds planted with hydrilla revealed a substantial Hydrellia spp. population throughout the facility. These samples were taken during late December 1998, and full summaries of the data have not been completed. However, in some ponds, nearly 100 percent of the stems had some form of damage, and in some cases, percentage of damaged leaves exceeded 15 percent. Both pupae and larvae were observed regularly. Such high amounts of damage indicate a large and flourishing Hydrellia spp. population especially considering these observations were made during the winter months. Again, how the insects become established at this facility is unknown since closest established populations are over $160 \mathrm{~km}$ away. 


\section{Summary}

Populations of Hydrellia spp. appear to be established throughout eastern Texas. Hydrellia pakistanae seems to be more widespread and found in higher numbers at most sites relative to population levels of $H$. balciunasi. Populations of $H$. pakistanae, albeit low at many locations, seem to be expanding in range with several new populations being discovered in areas where no releases have previously been made. These include several ponds at the LAERF and on the Rio Grande near Brownsville, TX. Hydrellia balciunasi also seems to be expanding in range, although at a slower pace than H. pakistanae, with new populations being observed at Lake Cypress Springs. At Lake Cypress Springs, releases were made during 1997, but only $H$. pakistanae was introduced.

While populations of either species of Hydrellia spp. are low at many locations, at some sites, insect populations may have reached high enough levels to apparently impact the hydrilla. For example, at Coleto Creek Reservoir, populations of $H$. pakistanae were high enough to evidently impact the hydrilla at two of the original release sites. Another site where Hydrellia spp. may be stressing the plants based on observed damage includes Lake Raven at Huntsville State Park.

Because of the relatively high numbers of sites in Texas where Hydrellia spp. was found but no introductions were made, research should concentrate, in part, on conducting surveys of as many hydrilla sites as possible. This will allow further documentation of the spread of the introduced Hydrellia spp. and to determine population sizes and impacts. In addition, sites where Hydrellia spp. may have impacted hydrilla should be examined more frequently especially through the active growing season to document insect and plant population changes. This information should be used in conjunction with the research being accomplished on plant nutritional effects on the insect agents to determine why populations of the insects, while expanding in distribution, do not rapidly reach high and damaging levels under field circumstances. Another important consideration is to coordinate the research on the hydrilla agents with work being accomplished examining the impact insect herbivory has on reducing the competitive ability of hydrilla. 


\section{References}

Buckingham, G. R., Okrah, E. A., and Thomas, M. C. (1989). "Laboratory host range tests with Hydrellia pakistanae (Diptera: Ephydridae), an agent for biological control of Hydrilla verticillata (Hydrocharitaceae)," Environ. Entomol.18, 164-71.

Center, T. D., Grodowitz, M. J., Cofrancesco, A. F., Jubinsky, G., Snoddy, E., and Freedman, J. E. (1997). "Establishment of Hydrellia pakistanae (Diptera: Ephydridae) for the biological control of the submersed aquatic plant Hydrilla verticillata (Hydrocharitaceae) in the southeastern United States," Biological Control 8, 65-73.

Grodowitz M. J., Center, T. D., Cofrancesco, A. F., and Freedman, J. E. (1997). "Release and establishment of Hydrellia balciunasi (Diptera:

Ephydridae) for the biological control of the submersed aquatic plant Hydrilla verticillata (Hydrocharitaceae) in the United States," Miscellaneous Paper A-97-5, U.S. Army Engineer Waterways Experiment Station, Vicksburg, MS.

Grodowitz, M. J., and Snoddy, E. (1992). "Release and establishment of insect biocontrol agents of hydrilla in Alabama, Louisiana, and Texas." Proceedings, 26th Annual Meeting, Aquatic Plant Control Research Program. Miscellaneous Paper A-92-2, U.S. Army Engineer Waterways Experiment Station, Vicksburg, MS, 226-233.

Smart, R. M., and Doyle, R. D. (1995). "Ecological theory and management of submersed aquatic plant communities," Information Exchange Bulletin A-95-3, Aquatic Plant Control Research Program, U.S. Army Engineer Waterways Experiment Station, Vicksburg, MS. 


\section{REPORT DOCUMENTATION PAGE}

Public reporting burden for this collection of information is estimated to average 1 hour per response, including the time for reviewing instructions, searching existing data sources, gathering and maintaining

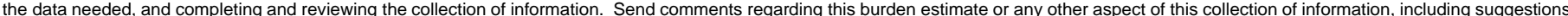

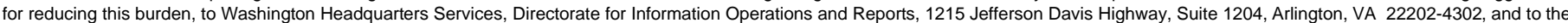
Office of Management and Budget, Paperwork Reduction Project (0704-0188), Washington, DC 20503.
1. AGENCY USE ONLY (Leave blank)
2. REPORT DATE
September 1999
3. REPORT TYPE AND DATES COVERED
Final report

\section{TITLE AND SUBTITLE}

Status of Hydrellia spp. (Diptera: Ephydridae) Release Sites in Texas as of December 1998

\section{AUTHOR(S)}

Michael J. Grodowitz, Jan E. Freedman, Alfred F. Cofrancesco, Ted D. Center

\section{PERFORMING ORGANIZATION NAME(S) AND ADDRESS(ES)}

U.S. Army Engineer Research and Development Center

Environmental Laboratory

3909 Halls Ferry Road, Vicksburg, MS 39180-6199;

5. FUNDING NUMBERS

Aquatic Plant Research Facility, 3205 College Avenue

Fort Lauderdale, FL 33314

9. SPONSORING/MONITORING AGENCY NAME(S) AND ADDRESS(ES)

U.S. Army Corps of Engineers

Washington, DC 20314-1000

\section{PERFORMING ORGANIZATION} REPORT NUMBER

Miscellaneous Paper A-99-1

\section{SUPPLEMENTARY NOTES}

Available from National Technical Information Service, 5285 Port Royal Road, Springfield, VA 22161.

12a. DISTRIBUTION/AVAILABILITY STATEMENT

12b. DISTRIBUTION CODE

Approved for public release; distribution is unlimited.

\section{ABSTRACT (Maximum 200 words)}

Beginning in 1991 and continuing through the present, two species of introduced Hydrellia (i.e., H. balciunasi and H. pakistanae) were released and their populations monitored at several sites in eastern and southeastern Texas. Currently, populations of the introduced Hydrellia spp. appear to be established throughout eastern Texas. Hydrellia pakistanae is more widespread and found in higher numbers at most sites relative to $H$. balciunasi. Levels of $H$. pakistanae, although low at many locations, seem to be expanding in range with several new populations being discovered in areas where no releases have previously been made. These include several ponds at the Lewisville Aquatic Ecosystem Research Facility and on the Rio Grande near Brownsville, TX. Hydrellia balciunasi also appears to be expanding in range, although at a slower pace than H. pakistanae. New populations of H. balciunasi were observed at Lake Cypress Springs near Mt. Vernon, TX, during 1997. At this location, releases of $H$. pakistanae were made during 1997, but only $H$. balciunasi was recovered during sampling conducted during 1998.

While populations of either species of Hydrellia spp. appear low at most locations, at some sites leaf-mining fly populations may have reached high enough levels to impact of hydrilla. For example, at Coleto Creek Reservoir, the hydrilla

14. SUBJECT TERMS
(Continued)

15. NUMBER OF PAGES

31

16. PRICE CODE

20. LIMITATION OF ABSTRACT

\section{SECURITY CLASSIFICATION OF REPORT \\ UNCLASSIFIED}

NSN 7540-01-280-5500

\section{SECURITY CLASSIFICATION OF THIS PAGE \\ UNCLASSIFIED} OF ABSTRACT

19. SECURITY CLASSIFICATION OF ABSTRACT

Standard Form 298 (Rev. 2-89) Prescribed by ANSI Std. Z39-18 298-102 


\section{3. (Concluded).}

was substantially reduced at two of the release sites during 1998 relative to what was observed during past sampling endeavors. Evidently, populations of $H$. pakistanae were high enough to impact the hydrilla at these sites since no other reason explaining the observed declines in the hydrilla is evident. Another location where Hydrellia spp. may be stressing the plants based on observed damage is Lake Raven at Huntsville State Park. 
Destroy this report when no longer needed. Do not return it to the originator. 